\title{
Clinical Characteristics and Remedy Profiles of Patients with COVID-19: A Retrospective Cohort Study
}

\author{
Bipin Jethani ${ }^{1}$ Meeta Gupta ${ }^{2}$ Parul Wadhwani ${ }^{1} \quad$ Rekha Thomas $^{1}$ Thankaraj Balakrishnan ${ }^{1}$ \\ George Mathew ${ }^{1}$ Mohit Mathur ${ }^{1}$ Bachha Pompi Rao ${ }^{2}$ Dhananjay Shukla ${ }^{1}$ Aashima Khullar ${ }^{1}$ \\ Meghna Khera ${ }^{1}$ Himani Sharma ${ }^{1}$ Ravinder Kumar ${ }^{1}$ Sudeep Kumar ${ }^{1}$ Sayami Jaggi ${ }^{1}$ Robin Sinha ${ }^{3}$ \\ Kamal Rawal ${ }^{3}$ Anu Kapoor ${ }^{1}$ Raj Kumar Manchanda ${ }^{1}$
}

${ }^{1}$ Nehru Homoeopathic Medical College and Hospital, Defence
Colony, New Delhi, India
2 Directorate of AYUSH, Govt. of Delhi, India
${ }^{3}$ Center for Computational Biology and Bioinformatics, Amity
Institute of Biotechnology, Amity University, Noida, Uttar Pradesh,
India

Homeopathy 2021;110:86-93.
Address for correspondence Raj Kumar Manchanda, BHMS, MD (Hom), MBA (Health Care), Nehru Homoeopathic Medical College and Hospital, Defence Colony, New Delhi 110024, India (e-mail: rkmanchanda@gmail.com).

\begin{abstract}
Keywords

- COVID-19

- SARS-CoV-2 infection

- Genus Epidemicus

- Homeopathy

Objective The aim of the study was to identify indicated homeopathic remedies based on the clinical characteristics of coronavirus disease 2019 (COVID-19) patients in India.

Methods In this retrospective, cohort study, confirmed COVID-19 patients admitted at a COVID Health Centre in New Delhi between April 29 and June 17, 2020 were given conventional and homeopathic treatment. Patients were grouped into mild, moderate or severe categories of disease. Their symptomatologic profiles were analyzed to identify indicated homeopathic medicines.

Results A total of 196 COVID-19 patients were admitted. One hundred and seventyeight patients had mild symptoms; eighteen patients had moderate symptoms; no patients with severe symptoms were included as they were referred to tertiary care centers with ventilatory support. The mean age of patients with mild symptoms was significantly lower (38.6 years; standard deviation or $S D \pm 15.8$ ) compared with patients in the moderate category (66.0 years; $S D \pm 9.09)$. The most important symptoms identified were fever (43.4\%), cough (47.4\%), sore throat $(29.6 \%)$, headache $(18.4 \%)$, myalgia (17.9\%), fatigue $(16.8 \%)$, chest discomfort $(13.8 \%)$, chills $(12.6 \%)$, shortness of breath $(11.2 \%)$ and loss of taste $(10.2 \%)$. Twenty-eight homeopathic medicines were prescribed, the most frequently indicated being Bryonia alba (33.3\%), Arsenicum album (18.1\%), Pulsatilla nigricans (13.8\%), Nux vomica (8\%), Rhus toxicodendron (7.2\%) and Gelsemium sempervirens (5.8\%), in 30C potency. Conclusion Data from the current study reveal that Arsenicum album, Bryonia alba, Pulsatilla nigricans, Nux vomica, Rhus toxicodendron and Gelsemium sempervirens are the most frequently indicated homeopathic medicines. A randomized controlled clinical trial based on this finding is the next step.
\end{abstract}

received

July 18,2020

accepted after revision

September 11, 2020

published online

February 8, 2021 (c) 2021. The Faculty of Homeopathy.

All rights reserved.

Georg Thieme Verlag KG,

Rüdigerstraße 14,

70469 Stuttgart, Germany
DOI https://doi.org/ 10.1055/s-0040-1718584. ISSN 1475-4916. 


\section{Introduction}

In December 2019, clusters of pneumonia cases were identified in Wuhan, China, caused by a newly identified $\beta$ coronavirus, named as severe acute respiratory syndrome coronavirus 2 (SARS-CoV-2). ${ }^{1}$

The classical clinical presentation is a severe acute respiratory infection ranging from a mild common cold-like illness to a severe viral pneumonia leading to potentially fatal SARS. ${ }^{2}$ Recent case reports suggest that coronavirus disorder 2019 (COVID-19) is a complex systemic disorder with extra-pulmonary manifestations, possibly due to viralinduced inflammation, affecting ACE2 (angiotensin-converting enzyme 2) receptors present in tissues other than lungs. ${ }^{3,4}$

Although COVID-19 is a polymorphic disease, its severity is classified on the basis of respiratory manifestations: mild (uncomplicated upper respiratory tract infection without evidence of breathlessness or hypoxia; $\mathrm{SpO}_{2}>94 \%$ ); moderate (pneumonia with no signs of severe disease, $\mathrm{SpO}_{2}<94 \%$ [90-94\%] on room air, respiratory rate more than or equal to $24 / \mathrm{min}$ ); severe (clinical signs of pneumonia plus one of the following; respiratory rate $>30$ breaths/min, severe respiratory distress, $\left.\mathrm{SpO}_{2}<90 \%\right)^{5}$

COVID-19 has affected over 20 million individuals worldwide, causing a large number of deaths and posing a serious threat to public health. ${ }^{6}$ In India, as of July 13, 2020, nearly 0.9 million patients have tested positive, of whom more than 0.1 million are from Delhi. ${ }^{7}$

This pandemic has led researchers and health care organizations to develop strategies to combat this infectious disease through repurposed drugs, vaccines and control measures. ${ }^{8}$ Evidence from laboratory, animal and clinical studies, and clinical trials on conventional medicine drugs such as remdesivir, ${ }^{9}$ lopinavir/ritonavir, ${ }^{10}$ lopinavir/ritonavir with interferon $\beta-1 \mathrm{a},{ }^{11}$ chloroquine, ${ }^{12,13}$ and hydroxychloroquine, ${ }^{14}$ have been reported. Treatment with convalescent plasma has been proposed as a potential treatment in severe cases. ${ }^{15}$ To date, however, no anti-SARS-CoV-2 drug or vaccine has been officially approved due to the absence of adequate evidence. ${ }^{16}$ So far, the therapeutic strategies to deal with this pandemic are conservative, with limited options in terms of treatment modalities.

The pandemic has uniquely challenged health care decision makers and the medical research community worldwide due to the absence of a vaccine or proven therapy. There is a potential role for a prudent strategy to integrate traditional medicine with conventional medicine to combat the present situation. ${ }^{17}$ A recent systematic review suggested that the integration of traditional Chinese medicine with "western medicine" improved cure rate with better symptom amelioration in COVID-19. ${ }^{18}$ Similarly, homeopathy could also be seen as a potential adjunct to conventional medicine.

Homeopathy has a long-standing history in the management of epidemic diseases. ${ }^{19}$ In terms of the evidence base, homoeopathy trials have pursued the following: tested preventive homeopathic medicines, where the focus has been on finding an effective universal prophylactic medicine $^{20-22}$; or tested the efficacy of individualized homeopathic treatment for patients with the disease ${ }^{23-25}$; or tested the adjunctive effectiveness of homeopathic treatment. ${ }^{26,27}$ Testing one medicine as Genus Epidemicus (GE) does not appear to be appropriate for the present pandemic due to its kaleidoscopic manifestation; nor has a potential GE been discerned. $^{28}$

The potential of homeopathic treatment on a large scale can be tested by following a step-wise process. The first step is characterization of data of COVID-19-positive patients and identification of probable effective remedies. The second step will be to evaluate the efficacy of these remedies through a high-quality randomized controlled trial (RCT). If a remedy or group of remedies is found to be efficacious, these can then be integrated in the treatment protocols of COVID patients. The third step might then be to explore the potential of these remedies in preventing the disease through rigorous RCTs in high-risk population groups and disease hot spots. ${ }^{29}$

This article addresses the above first step: systematic characterization of the clinical presentation of COVID-19 in Indian patients, and identification of corresponding homeopathic medicines for incorporation in treatment regimens. It is expected to be a stepping-stone for further studies for systematic validation.

\section{Objectives}

The primary objective was to identify the clinical presentation of laboratory-confirmed COVID-19 patients and identify a group of indicated homeopathic remedies based on their symptomatologic profile.

The secondary objective was to compare the collected data with those from similar studies in order to inform the design of a suitable RCT.

\section{Materials and Methods}

\section{Setting}

Nehru Homeopathic Medical College and Hospital (NHMCH), Defense Colony, New Delhi, was designated as a COVID Health Centre by the Department of Health and Family Welfare, Government of NCT of Delhi, for the isolation and treatment of COVID-19-positive patients, providing integrated care comprising conventional treatment (analgesic, antiallergic, anti-tussive, antibiotics) and adjunctive individualized homeopathic treatment. ${ }^{30}$ Six homeopathic doctors, Junior Residents pursuing post-graduation and four conventional doctors were deputed in a duty roster of $12 \mathrm{~h}$. All infection control guidelines, including use of appropriate personal protection equipment, were followed by the medical as well as support staff.

Development of the protocol and study design, manuscript writing, and coordination was done by doctors with 20 years of experience. The ethical clearance from the Institutional Ethics Committee was obtained on June 2, 2020 for undertaking retrospective analysis of patients admitted in the hospital. 
Patients signed an informed consent form at the time of admission for add-on homeopathic treatment and subsequent data analysis and publication. A patient case record form (CRF) was used for case taking, based on the World Health Organization (WHO) format for COVID-19. ${ }^{31}$ The patient data were anonymized by removing direct identifier variables for the analysis. The patients were jointly treated by this medical team and the work was supervised by doctors with 35 years' experience each. Epidemiological history, demographic data, clinical characteristics, laboratory data, treatment programs and outcome measures were obtained from the patients' medical records. Homeopathic characteristic data were obtained by daily follow-up during hospital stay. Initially the patients were discharged only after two consecutive negative tests for RT-PCR; later on, patients were discharged after complete recovery of symptoms, usually between 10 and 17 days as per the government guidelines.

\section{Participants}

Laboratory confirmed COVID-19-positive (reported positive on RT-PCR testing) symptomatic patients were admitted to NHMCH between April 29, 2020 and June 17, 2020.

\section{Variables}

These comprised demographic details and clinical symptoms of COVID-19-positive patients.

\section{Data Sources}

The CRFs of all admitted COVID-19-positive patients were analyzed retrospectively. Patients having common and characteristic symptoms were identified. ${ }^{32}$ Homeopathic medicines were prescribed to patients in addition to standard conventional treatment. ${ }^{33}$ Initially cases were prescribed after symptom repertorization, but later on, when the symptoms of patients followed a commonly recognized pattern, the same remedy was given. Prescribing indication(s) and the most prominent symptom(s) were specifically recorded to assess potential effectiveness, despite concurrent use of a conventional drug.

\section{Results}

A total of 196 patients were admitted during the time frame. Fifty-eight patients did not give consent to receive add-on homeopathic treatment. The average age of patients was 38.9 years (standard deviation, 16.3; range, 2-92 years); 54 (27.55\%) were female and $142(72.45 \%)$ were male. The mean age of patients with mild symptoms was $38.6 \pm 15.8$ years. The mean age of patients with moderate symptoms was $66.0 \pm 9.1$ years. No patients with severe symptoms were seen. Eighty-three (42.35\%) patients had a positive contact history, whilst the history was unknown for 113 (57.65\%) patients (-Table $\mathbf{1}$ ).

The majority of patients (90.8\%) were within the mild category $(n=178)$ and the rest $(9.2 \%)$ were categorized as moderate $(n=18)$. A total of $153(78 \%)$ patients were discharged after complete recovery of all symptoms. Ten cases
Table 1 Demographic details

\begin{tabular}{|c|l|l|l|}
\hline & $\begin{array}{l}\text { Total } \\
(\boldsymbol{n}=196)\end{array}$ & $\begin{array}{l}\text { Mild } \\
(\boldsymbol{n}=\mathbf{1 7 8 )}\end{array}$ & $\begin{array}{l}\text { Moderate } \\
(\boldsymbol{n}=\mathbf{1 8})\end{array}$ \\
\hline Age & & $38.6 \pm 15.8$ & $66.0 \pm 9.1$ \\
\hline Mean & $38.9 \pm 16.3$ & 35 & 68 \\
\hline Median & 35.5 & & \\
\hline Gender & & 128 & 14 \\
\hline Male & 142 & 50 & 4 \\
\hline Female & 54 & & \\
\hline
\end{tabular}

(5.1\%) deteriorated due to persistent fever, breathlessness and oxygen concentration $<90 \%$, and were then considered under the severe category. Remedies were worked out after repertorization of these severe cases, but since the study hospital setting did not have an intensive care unit to manage severe or critical cases, these patients were transferred and could not be evaluated for outcome from the adjunctive homeopathic medicines. The mean duration of stay of the 196 patients patients at $\mathrm{NHMCH}$ was 13 days (10-17 days). The predominant symptoms of disease were cough (47.4\%), fever (43.4\%) and sore throat (29.6\%) (- Table 2 ).

The detailed homeopathic clinical analysis of major symptoms revealed that fever was predominantly low grade with

Table 2 Details of clinical characteristics of COVID-19 patients

\begin{tabular}{|l|l|l|}
\hline Symptoms & $\boldsymbol{n}$ & $\%$ \\
\hline Cough & 93 & $47.45 \%$ \\
\hline Fever & 85 & $43.37 \%$ \\
\hline Sore throat & 58 & $29.59 \%$ \\
\hline Headache & 36 & $18.37 \%$ \\
\hline Myalgia or arthralgia & 35 & $17.86 \%$ \\
\hline Fatigue & 33 & $16.84 \%$ \\
\hline Chest discomfort & 27 & $13.78 \%$ \\
\hline Shortness of breath & 22 & $11.22 \%$ \\
\hline Loss of taste & 20 & $10.20 \%$ \\
\hline Dryness of mouth & 19 & $9.69 \%$ \\
\hline Nasal coryza & 17 & $8.67 \%$ \\
\hline Constipation & 16 & $8.16 \%$ \\
\hline Diarrhea & 13 & $6.63 \%$ \\
\hline Abdominal pain & 12 & $6.12 \%$ \\
\hline Nausea & 12 & $6.12 \%$ \\
\hline Vomiting & 10 & $5.10 \%$ \\
\hline Nasal blockage & 7 & $3.57 \%$ \\
\hline Loss of smell & 7 & $3.57 \%$ \\
\hline Retrosternal burning & 5 & $2.55 \%$ \\
\hline Sneezing & 5 & $2.55 \%$ \\
\hline Hemoptysis & 1 & $0.51 \%$ \\
\hline
\end{tabular}

Abbreviation: COVID-19, coronavirus disease 2019. 
prolonged heat stage (17.8\%), with the concomitant symptom of dryness of mouth (9.7\%). Dry cough was reported in 50 (25.5\%) patients, whilst sputum during cough was reported in $43(21.9 \%)$ patients. Amongst the 43 patients with productive cough, it was observed that $28(14.2 \%)$ had easy expectoration and 19 (9.6\%) had whitish sputum (-Table 3 ).

Homeopathic treatment was provided to 138 patients alongside standard conventional treatment. Cases were repertorized with Synthesis Repertory Radar Opus, with special emphasis on characteristic symptoms. Repertorial analysis of the collective symptoms of these patients indicated 28 medicines in total. Medicines were given in different potencies (LM, 30C, 200C). The most frequently used medicines were Bryonia alba (33.3\%), Arsenicum album (18.1\%), Pulsatilla nigricans (13.8\%), Nux vomica (8\%), Rhus toxicodendron (7.2\%), and Gelsemium sempervirens (5.8\%). 30C was the most commonly used potency $(n=120)$ ( - Table 4).

Subsequently, patients' expression (symptoms) and signs (objective clinical features) of disease were extracted from CRFs. These were converted into rubrics (group keywords) using a dictionary-based approach (repertory). This information was compiled for the top six medicines: namely Bryonia alba, Arsenicum album, Pulsatilla nigricans, Nux vomica, Rhus toxicodendron, and Gelsemium sempervirens (-Table 5).

\section{Discussion}

The full-recovery rate of COVID-19-positive patients was 78\% and the average duration of stay in the hospital was 13 days.

Table 3 Detailed clinical analysis of chief symptoms

\begin{tabular}{|c|c|c|}
\hline $\begin{array}{l}\text { Chief } \\
\text { complaint }\end{array}$ & \multicolumn{2}{|l|}{ Characteristic } \\
\hline \multirow[t]{3}{*}{$\begin{array}{l}\text { Fever }(n=85) \\
(43.3 \%)\end{array}$} & $\begin{array}{l}\text { Low grade } \\
\left(<37.5-38.3^{\circ} \mathrm{C}\right) \\
(n=62)(31.6 \%)\end{array}$ & $\begin{array}{l}\text { Chill }(n=18) \\
(9.1 \%)\end{array}$ \\
\hline & \multirow[t]{2}{*}{$\begin{array}{l}>38.3^{\circ} \mathrm{C}(n=23) \\
(11.7 \%)\end{array}$} & $\begin{array}{l}\text { Heat }(n=35) \\
(17.8 \%)\end{array}$ \\
\hline & & $\begin{array}{l}\text { Perspiration } \\
(n=12)(6.1 \%)\end{array}$ \\
\hline \multirow[t]{9}{*}{$\begin{array}{l}\text { Cough }(n=93) \\
(47.4 \%)\end{array}$} & $\begin{array}{l}\text { Dry }(n=50) \\
(25.5 \%)\end{array}$ & $\begin{array}{l}\text { Thirst increased } \\
(n=30)(15.3 \%)\end{array}$ \\
\hline & \multirow{8}{*}{$\begin{array}{l}\text { Productive }(n=43) \\
(21.9 \%)\end{array}$} & Expectoration: \\
\hline & & $\begin{array}{l}\text { Easy }(n=28) \\
(14.2 \%)\end{array}$ \\
\hline & & $\begin{array}{l}\text { Difficult }(n=8) \\
(4.1 \%)\end{array}$ \\
\hline & & Color: \\
\hline & & $\begin{array}{l}\text { White }(n=19) \\
(9.6 \%)\end{array}$ \\
\hline & & $\begin{array}{l}\text { Yellow }(n=16) \\
(8.1 \%)\end{array}$ \\
\hline & & $\begin{array}{l}\text { Transparent } \\
(n=3)(1.5 \%)\end{array}$ \\
\hline & & $\begin{array}{l}\text { Bloody }(n=1) \\
(0.5 \%)\end{array}$ \\
\hline
\end{tabular}

The condition of $5.1 \%$ patients deteriorated during the study and they were referred to a tertiary care center with ventilator support. Though improvement and recovery were observed in most cases, further studies are needed to evaluate the outcome from homeopathic medicines on variables such as time to clinical improvement and laboratory parameters.

Homeopathic medicines were given in conjunction with standard conventional treatment and it was observed that most of the patients under this hybrid system (standard protocol plus homeopathy) recovered without major complications. The effectiveness of the homeopathy element of this combined protocol might be explored in subsequent studies by comparing conventional treatment plus homeopathic treatment with conventional treatment plus placebo.

Datasets from clinical studies conducted at various hospitals internationally were compiled to compare their clinical and demographic features with those of Indian COVID-19 patients. Most of the top-ranking symptoms observed in this study were also found in an observational study by Guan et al, except for much greater prevalence of sore throat in the current study. ${ }^{4}$ Similar comparison with data reported in a cohort study of 41 patients undertaken by Huang et al in Wuhan underscores that finding. ${ }^{34}$ Another similar study reported that Bryonia alba and Arsenicum album are the most frequently prescribed medicines (in 30C potency) for symptomatic COVID-19-positive patients treated by homeopathic physicians in Italy. ${ }^{35}$ Others reported that Bryonia alba and Gelsemium sempervirens were the most commonly prescribed medicines in 18 mild COVID-19 cases in Hong Kong. ${ }^{36}$

The current study has paved a way to conduct a multicenter, prospective, randomized double-blind controlled trial of homeopathic medicines for COVID-19 patients using the identified medicines.

COVID-19 has presented a challenge for the scientific community in terms of size of dataset and heterogeneity. The homeopathy community is facing similar challenges in terms of fragmented initiatives, lack of high-quality clinical data, unavailability of trained manpower, issues with data collection, and lack of high quality observational and controlled studies. Artificial intelligence systems such as "machine learning" (ML) can play an important role in addressing these challenges. ${ }^{37-41}$ Future studies in ML can provide datadriven clinical decision-making for improving treatment outcomes, consistency in prescribing, identification of a set of medicines useful in COVID-19, and identification of repurposed existing drugs. When large datasets become available, ML algorithms will be used and reported in a future publication from our research group.

\section{Study Limitations}

Although the majority of cases improved and were discharged, the positive outcome cannot be solely attributed to homeopathic medicines since patients were also given conventional drugs. This disease is also known for its selflimiting course of 5 to 14 days in mild cases, and there was no control arm to assess the effectiveness. The institute had limited laboratory resources and no radiology support. 
90 Characteristics and Remedy Profile of Patients with COVID-19 Jethani et al.

Table 4 Homeopathic medicines prescribed $(n=138)$

\begin{tabular}{|c|c|c|}
\hline Homeopathic medicine & $n$ & $\%$ \\
\hline Bryonia alba & 46 & $33.33 \%$ \\
\hline $30 \mathrm{C}$ & 32 & \\
\hline $200 \mathrm{C}$ & 14 & \\
\hline Arsenicum album & 25 & $18.12 \%$ \\
\hline $30 \mathrm{C}$ & 24 & \\
\hline $200 C$ & 1 & \\
\hline Pulsatilla nigricans & 19 & $13.77 \%$ \\
\hline $30 \mathrm{C}$ & 17 & \\
\hline $200 C$ & 2 & \\
\hline Nux vomica & 11 & $7.97 \%$ \\
\hline $30 \mathrm{C}$ & 8 & \\
\hline $200 \mathrm{C}$ & 3 & \\
\hline Rhus toxicodendron & 10 & $7.25 \%$ \\
\hline $30 \mathrm{C}$ & 9 & \\
\hline $200 \mathrm{C}$ & 1 & \\
\hline Gelsemium sempervirens & 8 & $5.79 \%$ \\
\hline $30 \mathrm{C}$ & 6 & \\
\hline $200 C$ & 2 & \\
\hline Sulphur & 7 & $5.07 \%$ \\
\hline $30 \mathrm{C}$ & 2 & \\
\hline $200 C$ & 5 & \\
\hline Spongia tosta & 5 & $3.62 \%$ \\
\hline $30 \mathrm{C}$ & 3 & \\
\hline $200 \mathrm{C}$ & 2 & \\
\hline Hepar sulphuricum & 3 & $2.17 \%$ \\
\hline $30 \mathrm{C}$ & 2 & \\
\hline $200 \mathrm{C}$ & 1 & \\
\hline Phosphorus $30 \mathrm{C}$ & 3 & $2.17 \%$ \\
\hline Lycopodium clavatum $30 \mathrm{C}$ & 2 & $1.45 \%$ \\
\hline Ammonium carbonicum $30 \mathrm{C}$ & 1 & $0.72 \%$ \\
\hline Calcarea phosphorica $30 \mathrm{C}$ & 1 & $0.72 \%$ \\
\hline Carbo vegetabilis $30 \mathrm{C}$ & 1 & $0.72 \%$ \\
\hline Coccus cacti $30 \mathrm{C}$ & 1 & $0.72 \%$ \\
\hline Ferrum metallicum $30 \mathrm{C}$ & 1 & $0.72 \%$ \\
\hline Ferrum phoshorica $30 \mathrm{C}$ & 1 & $0.72 \%$ \\
\hline Ipecacuanha $30 \mathrm{C}$ & 1 & $0.72 \%$ \\
\hline Sanguinaria canadensis $30 \mathrm{C}$ & 1 & $0.72 \%$ \\
\hline Stannum metallicum $30 \mathrm{C}$ & 1 & $0.72 \%$ \\
\hline Aconitum napellus $200 \mathrm{C}$ & 1 & $0.72 \%$ \\
\hline Belladonna $200 \mathrm{C}$ & 1 & $0.72 \%$ \\
\hline Calcarea carbonica 200 C & 1 & $0.72 \%$ \\
\hline Camphora $200 \mathrm{C}$ & 1 & $0.72 \%$ \\
\hline Cinchona officinalis $200 \mathrm{C}$ & 1 & $0.72 \%$ \\
\hline
\end{tabular}

Table 4 (Continued)

\begin{tabular}{|l|l|l|}
\hline Homeopathic medicine & $\boldsymbol{n}$ & $\%$ \\
\hline Hyoscyamus 200 C & 1 & $0.72 \%$ \\
\hline Justicia adhatoda Q & 1 & $0.72 \%$ \\
\hline Baptisia tinctoria Q & 1 & $0.72 \%$ \\
\hline
\end{tabular}

Table 5 Prescribing indications of remedies based on repertorial totality

\begin{tabular}{|c|c|c|}
\hline Medicine & Rubrics & $\begin{array}{l}\text { No. of cases } \\
\text { observed }\end{array}$ \\
\hline \multirow{15}{*}{$\begin{array}{l}\text { cBryonia } \\
\text { alba }\end{array}$} & General: slow manifestation & 46 \\
\hline & Cough: dry, fever during & 37 \\
\hline & $\begin{array}{l}\text { Stomach: thirst, large } \\
\text { quantities, for }\end{array}$ & 23 \\
\hline & Stool: constipation & 16 \\
\hline & $\begin{array}{l}\text { Generals: pain, bones, as if } \\
\text { broken }\end{array}$ & 16 \\
\hline & Mouth: dryness & 14 \\
\hline & Fever: night, dry burning & 11 \\
\hline & Head: pain, cough during & 10 \\
\hline & Throat: dryness & 9 \\
\hline & $\begin{array}{l}\text { Mind: irritability, during } \\
\text { headache }\end{array}$ & 8 \\
\hline & $\begin{array}{l}\text { Throat: pain, swallowing, } \\
\text { agg. }\end{array}$ & 6 \\
\hline & Cough, motion aggravates & 6 \\
\hline & Head: pain, bursting & 5 \\
\hline & $\begin{array}{l}\text { Head: pain, pressure } \\
\text { ameliorate }\end{array}$ & 5 \\
\hline & Mouth: taste, bitter & 5 \\
\hline \multirow[t]{10}{*}{$\begin{array}{l}\text { Arsenicum } \\
\text { album }\end{array}$} & $\begin{array}{l}\text { General: weakness, fever } \\
\text { during }\end{array}$ & 21 \\
\hline & $\begin{array}{l}\text { Stomach: thirst, small } \\
\text { quantities for }\end{array}$ & 15 \\
\hline & $\begin{array}{l}\text { General: warm applications } \\
\text { ameliorate }\end{array}$ & 13 \\
\hline & Fever with chill & 13 \\
\hline & $\begin{array}{l}\text { Throat: pain, warm drinks } \\
\text { ameliorate }\end{array}$ & 12 \\
\hline & Chest: pain, burning & 10 \\
\hline & Mind: anxiety, lying & 6 \\
\hline & Chill: morning & 6 \\
\hline & $\begin{array}{l}\text { Extremities: pain, feet, so- } \\
\text { les, burning }\end{array}$ & 5 \\
\hline & $\begin{array}{l}\text { Chill, alternating with } \\
\text { perspiration }\end{array}$ & 5 \\
\hline \multirow[t]{2}{*}{$\begin{array}{l}\text { Pulsatilla } \\
\text { nigricans }\end{array}$} & $\begin{array}{l}\text { Mouth: taste, wanting, loss } \\
\text { of taste }\end{array}$ & 14 \\
\hline & Stomach: thirstless & 13 \\
\hline
\end{tabular}


Table 5 (Continued)

\begin{tabular}{|c|c|c|}
\hline Medicine & Rubrics & $\begin{array}{l}\text { No. of cases } \\
\text { observed }\end{array}$ \\
\hline & Expectoration, thick & 11 \\
\hline & Expectoration, yellow & 11 \\
\hline & $\begin{array}{l}\text { Abdomen: pain, stool } \\
\text { before }\end{array}$ & 8 \\
\hline & Nose: smell, wanting & 5 \\
\hline & Mouth: dryness, thirstless & 5 \\
\hline & Expectoration: difficult & 5 \\
\hline \multirow[t]{10}{*}{ Nux vomica } & Chills: morning & 8 \\
\hline & $\begin{array}{l}\text { Throat: pain, warm drinks } \\
\text { ameliorate }\end{array}$ & 8 \\
\hline & Chill: violent & 7 \\
\hline & Mouth: taste, bitter & 6 \\
\hline & Chest: pain, burning & 6 \\
\hline & $\begin{array}{l}\text { Rectum: constipation, inef- } \\
\text { fectual urging and straining }\end{array}$ & 6 \\
\hline & $\begin{array}{l}\text { Mouth: taste, wanting, loss } \\
\text { of taste }\end{array}$ & 5 \\
\hline & $\begin{array}{l}\text { Stomach: vomiting, eating } \\
\text { after, agg. }\end{array}$ & 5 \\
\hline & Abdomen: pain, burning & 5 \\
\hline & Nose: smell, wanting & 4 \\
\hline \multirow[t]{8}{*}{$\begin{array}{l}\text { Rhus } \\
\text { toxicodendron }\end{array}$} & $\begin{array}{l}\text { Extremities: pain, joints, } \\
\text { chill during }\end{array}$ & 8 \\
\hline & Generals: pain, sore & 6 \\
\hline & $\begin{array}{l}\text { Cough: warm drinks } \\
\text { ameliorate }\end{array}$ & 6 \\
\hline & Mouth: taste, altered & 5 \\
\hline & Back: pain, sore & 5 \\
\hline & $\begin{array}{l}\text { Throat: pain, warmth } \\
\text { ameliorates }\end{array}$ & 4 \\
\hline & Extremities: pain, shoulders & 4 \\
\hline & $\begin{array}{l}\text { Abdomen: pain, walking } \\
\text { ameliorates }\end{array}$ & 4 \\
\hline \multirow[t]{8}{*}{$\begin{array}{l}\text { Gelsemium } \\
\text { sempervirens }\end{array}$} & $\begin{array}{l}\text { General: slow manifestation } \\
\text { [of symptoms] }\end{array}$ & 8 \\
\hline & $\begin{array}{l}\text { Stomach: thirstless during } \\
\text { fever }\end{array}$ & 7 \\
\hline & $\begin{array}{l}\text { General: weakness, fever } \\
\text { during }\end{array}$ & 7 \\
\hline & $\begin{array}{l}\text { Sleep: sleepiness, heat } \\
\text { during }\end{array}$ & 5 \\
\hline & Head: heaviness & 5 \\
\hline & $\begin{array}{l}\text { Head: pain, forehead, lying } \\
\text { agg. }\end{array}$ & 4 \\
\hline & $\begin{array}{l}\text { Head: pain, occiput, dull } \\
\text { pain }\end{array}$ & 4 \\
\hline & $\begin{array}{l}\text { Mind: quiet, wants to be, } \\
\text { during chill }\end{array}$ & 4 \\
\hline
\end{tabular}

\section{Conclusion}

Data from the current study in New Delhi reveal that Arsenicum album, Bryonia alba, Pulsatilla nigricans, Nux vomica, Rhus toxicodendron and Gelsemium sempervirens were the most frequently indicated homeopathic medicines. It is desirable that randomized controlled clinical trials are instituted using these medicines and their identified indications.

\section{Highlights}

- Being a new disease, the first step toward identifying the potential effectiveness of homeopathy in COVID-19 is delineating the clinical presentation of this pandemic.

- A retrospective cohort study on laboratory-confirmed symptomatic patients was thus conducted in a COVID hospital in New Delhi, India.

- Based on symptomatology profile, six homeopathic medicines have been shortlisted for further evaluation.

\section{Authors' Contributions}

This study was conducted under the overall supervision of R.K.M., who contributed to the protocol, the critical evaluation of data and scrutiny of the manuscript. A.K. provided key insights into the homeopathic management of the patients, besides ensuring logistic support. Data collection was done by a team of doctors posted in the COVID ward (B.J., P.W., R.T., M.M., B.P.R., D.S.), assisted by As.K., M.K., H.S., R.K., S.K. and S.J. B.J., M.G., T.B. and G.M. helped in the development of the protocol, study design, and manuscript writing. K.R. and R.S. worked on data curation. All authors are responsible for and agreed to the content of the manuscript.

\section{Funding}

No separate financial support was sought for the conduct of the study; all contributors (except K.R. and R.S.) are fulltime staff employed by the Government of NCT of Delhi. Dr. Kamal Rawal acknowledges the grant provided by SERB, Department of Science and Technology, Government of India (Grant ID: BT/PR17252/BID/7/708/2016), for the study of repurposed drugs on COVID-19, as well as the support of the Ministry of AYUSH, Government of India.

Conflict of Interest

None declared.

\section{Acknowledgements}

The authors extend their sincere gratitude to Shri Satyendra Jain, Minister of Health and Family Welfare, Government of NCT of Delhi for facilitating this study by declaring Nehru Homoeopathic Medical College and Hospital, New Delhi, as a dedicated COVID Health Centre. We thank Dr. Neeraj Gupta and Shri Ishaan Pandit for providing administrative and technical support in the conduct of this study. We appreciate the contribution of conventional 
doctors, Aditya Nag, Kavita Trivedi, Anmol Giri, Parimal Patel, in giving standard treatment to patients. We thank Dr. Philippa Fibert for critical review and linguistic correction of the submitted manuscript.

We are grateful to Dr. Wilmar Schwabe India Ltd. for providing a set of homeopathic remedies used in this study. We acknowledge Laboratory colleagues (Kartik, Preeti P., Swarasat, Akshat Gupta, Akshit Gupta) of Dr. Kamal Rawal at Amity University for their assistance in data curation and compilation. We are indebted to all patients who consented to have their clinical history used for anonymized analysis, and to all medical and paramedical staff members of Nehru Homeopathic Medical College and Hospital.

\section{References}

1 Guo YR, Cao QD, Hong ZS, et al. The origin, transmission and clinical therapies on coronavirus disease 2019 (COVID-19) outbreak - an update on the status. Mil Med Res 2020;7:11

2 Guan WJ, Ni Z-Y, Hu Y, et al; China Medical Treatment Expert Group for Covid-19. Clinical characteristics of coronavirus disease 2019 in China. N Engl J Med 2020;382:1708-1720

3 Waisse S, Oberbaum M, Frass M. The hydra-headed coronaviruses: implications of COVID-19 for homeopathy. Homeopathy 2020;109:169-175

4 Tosato F, Giraudo C, Pelloso M, Musso G, Piva E, Plebani M. One disease, different features: COVID-19 laboratory and radiological findings in three Italian patients. Clin Chem Lab Med 2020; 58:1149-1151

5 Clinical Management Protocol. COVID-19. Directorate General of Health services. Ministry of Health and Family Welfare, Government of India Website. Available at: https://www.mohfw.gov.in/pdf/ClinicalManagementProtocolforCOVID19.pdf. Accessed August 19, 2020

6 Li H, Liu SM, Yu XH, Tang SL, Tang CK. Coronavirus disease 2019 (COVID-19): current status and future perspectives. Int J Antimicrob Agents 2020;55:105951

7 COVID-19 Dashboard. Ministry of Health and Family Welfare, Government of India Website. Available at: https://www.mygov.in/covid-19. Accessed July 13, 2020

8 Iyer M, Jayaramayya K, Subramaniam MD, et al. COVID-19: an update on diagnostic and therapeutic approaches. BMB Rep 2020; 53:191-205

9 Wang Y, Zhang D, Du G, et al. Remdesivir in adults with severe COVID-19: a randomised, double-blind, placebo-controlled, multicentre trial. Lancet 2020;395:1569-1578

10 Cao B, Wang Y, Wen D, et al. A trial of lopinavir-ritonavir in adults hospitalized with severe COVID-19. N Engl J Med 2020; 382:1787-1799

11 Sheahan TP, Sims AC, Leist SR, et al. Comparative therapeutic efficacy of remdesivir and combination lopinavir, ritonavir, and interferon beta against MERS-CoV. Nat Commun 2020;11:222

12 Gao J, Tian Z, Yang X. Breakthrough: chloroquine phosphate has shown apparent efficacy in treatment of COVID-19 associated pneumonia in clinical studies. Biosci Trends 2020;14:72-73

13 Savarino A, Di Trani L, Donatelli I, Cauda R, Cassone A. New insights into the antiviral effects of chloroquine. Lancet Infect Dis 2006;6:67-69

14 Yao X, Ye F, Zhang M. In vitro antiviral activity and projection of optimized dosing design of hydroxychloroquine for the treatment of severe acute respiratory syndrome coronavirus 2 (SARS-CoV2). Clin Infect Dis 2020;71:732-739

15 Chen L, Xiong J, Bao L, Shi Y. Convalescent plasma as a potential therapy for COVID-19. Lancet Infect Dis 2020;20:398-400
16 Li H, Zhou Y, Zhang M, Wang H, Zhao Q Liu J. Updated approaches against SARS-CoV-2. Antimicrob Agents Chemother 2020;64: e00483-e20

17 Ganguly S, Bakhshi S. Traditional and complementary medicine during COVID-19 pandemic. Phytother Res 2020. Doi: 10.1002/ ptr.6828

18 Liu M, Gao Y, Yuan Y, et al. Efficacy and safety of integrated traditional Chinese and Western medicine for Corona virus disease 2019 (COVID-19): a systematic review and meta-analysis. Pharmacol Res 2020;158:104896

19 Jacobs J. Homeopathic prevention and management of epidemic diseases. Homeopathy 2018;107:157-160

20 Nunes LAS. Homeopathy and dengue: Macaé, Rio de Janeiro, Brazil, 2007-2012. Rev Homeopatia 2016;79:1-16

21 Prass-Santos C, Brina NT, Magalhães IL, et al. Report on the use of homeopathic medication in the prophylaxis of dengue in Belo Horizonte, Minas Gerais, Brazil, in 2010. Rev Homeopatia 2012;75:1-12

22 Bracho G, Varela E, Fernández R, et al. Large-scale application of highly diluted bacteria for leptospirosis epidemic control. Homeopathy 2010;99:156-166

23 Hahnemann S. Organon of Medicine. 6th ed. New Delhi: B. Jain Publishers; 2004:267

24 Mathie RT, Baitson ES, Frye J, Nayak C, Manchanda RK, Fisher P. Homeopathic treatment of patients with influenza-like illness during the $2009 \mathrm{~A} / \mathrm{H} 1 \mathrm{~N} 1$ influenza pandemic in India. Homeopathy 2013;102:187-192

25 Chakraborty PS, Lamba CD, Nayak D, et al. Effect of individualized homoeopathic treatment in influenza like illness: a multicenter, single blind, randomized, placebo-controlled study. Indian J Res Homeopathy 2013;7:22-30

26 Oberai P, Varanasi R, Padmanabhan M, et al. Effectiveness of homeopathic medicines as add-on to institutional management protocol for acute encephalitis syndrome in children: an openlabel randomized placebo-controlled trial. Homeopathy 2018; 107:161-171

27 Nayak D, Chadha V, Jain S, et al. Effect of adjuvant homeopathy with usual care in management of thrombocytopenia due to dengue: a comparative cohort study. Homeopathy 2019;108:150-157

28 Vithoulkas G. COVID-19: Thoughts of Prof. G. Vithoulkas. Available at: https://www.vithoulkas.com/academy/newsletter-archive/2020-03-24/covid-19thoughts-prof-g-vithoulkas. Accessed July 13, 2020

29 Manchanda RK, Gupta M. Homoeopathy in the COVID-19 pandemic: opportunities, challenges and the road ahead. Available at: https://hpathy.com/homeopathy-papers/homeopathy-inthe-covid-19-pandemic-opportunities-challenges-and-theroad-ahead/. Accessed July 13, 2020

30 Guidelines for Homoeopathic Practitioners for COVID 19, Ministry of AYUSH, Government of India Website. Available at: https:// www.ayush.gov.in/docs/homeopathy-guidelines.pdf. Accessed July 13,2020

31 Global COVID-19: clinical platform: novel coronavirus (COVID19): rapid version. World Health Organization Website Available at: https://www.who.int/publications/i/item/global-covid-19clinical-platform-novel-coronavius-(-covid-19)-rapid-version. Accessed July 13, 2020

32 Rutten L, Muraleedharan KC, Shinde VH, Manchanda RK. What is a homoeopathic symptom, in daily practice and research? Indian J Res Homoeopathy 2017;11:12-20

33 Guidelines on Clinical Management of COVID-19. Directorate General of Health services. Ministry of Health and Family Welfare, Government of India Website Available at: https://www.mohfw. gov.in/pdf/GuidelinesonClinicalManagementofCOVID1912020. pdf. Accessed July 13, 2020

34 Huang C, Wang Y, Li X, et al. Clinical features of patients infected with 2019 novel coronavirus in Wuhan, China. Lancet 2020; 395:497-506 
35 Valeri A. Symptomatic COVID-19 positive and likely patients treated by homeopathic physicians-an Italian descriptive study. 2020. Available at: https://www.researchgate.net/publication/ 340631586. Accessed July 13, 2020

36 To KLA, Fok YYY. Homeopathic clinical features of 18 patients in COVID-19 outbreaks in Hong Kong. Homeopathy 2020; 109:146-162

37 Chilamkurthy S, Ghosh R, Tanamala S, et al. Deep learning algorithms for detection of critical findings in head CT scans: a retrospective study. Lancet 2018;392:2388-2396

38 Hatton CM, Paton LW, McMillan D, Cussens J, Gilbody S, Tiffin PA. Predicting persistent depressive symptoms in older adults: a machine learning approach to personalised mental healthcare. J Affect Disord 2019;246:857-860

39 Rajpurkar P, Irvin J, Ball RL, et al. Deep learning for chest radiograph diagnosis: a retrospective comparison of the CheXNeXt algorithm to practicing radiologists. PLoS Medicine 2018;15: e1002686

40 Ustun B, Westover B, Rudin C, Bianchi M. Clinical prediction models for sleep apnea: the importance of medical history over symptoms. J Clin Sleep Med 2016;12:161-168

41 Sadidpour SS, Ghidary SS. Remedy selection based on artificial intelligent methods. Int J Comput Appl 2011;19:6-9 